\title{
Factors Influencing the Implementation of International Public Sector Accounting Standards in Pakistan
}

\author{
Javed Miraj $^{1,2}$ \& Zhuquan Wang ${ }^{1}$ \\ ${ }^{1}$ College of Management, Ocean University of China, Qingdao, China \\ ${ }^{2}$ Lasbela University of Agriculture, Water and Marine Science, Uthal, Balochistan, Pakistan \\ Correspondence: Professor Zhuquan Wang, College of Management, Ocean University of China, Qingdao, \\ China.E-mail: javed_meraj2@hotmail.com
}

Received: May 21, 2019

doi:10.5539/ijbm.v14n9p15
Accepted: June 26, 2019

Online Published: August 5, 2019

\begin{abstract}
The significance and impact of Accrual-based Public Sector Accounting Standards (APSAS) in financial reporting has in recent times gained traction and has prompted debates which are aligned towards APSAS reporting. This implies that reforms in the government's management systems are becoming critical towards examination of actions and steps taken to enhance demands for better transparency and accountability in the management of public finance. As is presently presented in Pakistan, there are numerous fundamental challenges that currently inhibit the efficiency of the government's finance and accounting management. These problems arise due to poor supervision, poor management of basic financial functions, inefficient financial information including support for decision making, poor staff motivation and finally lack of proper accountability measures. Due to these arising challenges, the purpose of this study is to determine the factors affecting the implementation of Accrual-based International Public sector Accounting Standards (AIPSAS) in public sector of Pakistan. The study whose objective was to evaluate the barriers in the adoption of AIPSAS in Pakistan adopted a descriptive qualitative study model. A five-point Likert type scale was utilized to evaluate the results of the study. The study adopted simple randomization process to obtain the population sample group/respondents. The results of the research study recommended improvement of capacity building through training and offering educational courses which will help advance the enforcement of strong financial reporting standards.
\end{abstract}

Keywords: accrual-based public sector accounting standards, accountability, finance and accounting management, randomization, inefficient financial information

\section{Introduction}

Accrual accounting has for a while been the norm among multiple private sectors while a majority of government operational budgets were prepared on a cash basis for up to recent dates. Despite this, with recent national standards on accrual accounting designed for the public sector, governments have evolved and adopted this system due to its operational efficiency in multiple sectors (Sarim, 2017). The drive for accrual-based accounting can be attributed to many factors which include: (i) The advancements of accrual-based international standards to facilitate government fiscal and financial reporting, (ii) the exposed limitations of pure cash accounting, (iii) the development and efficiency of computerized financial management and (iv) professionalization of the government accounting cadre and the consequential introduction of private sector approaches on the public domain (Rauf et al., 2012). As a result of multiple deficits and shortcomings experienced by the Pakistani public sector, the government began to appreciate the significance of proper and accountable financial reporting system.

The increasing financial crises within the public domain stretching to the international market has raised the demand for proper and effective financial management in the public sector for a transparent financial report approach (Becker, 2014). This means that the public sector accounting is among the main determinants of the growth and development of a nation. Evidence from recent studies and other developing governments have indicated the prowess level of accrual-based accounting system if adopted to all government levels to have a high success index as opposed to the traditional cash system (Becker, 2014). Financial management has been defined as the planning, directing, and control of financial related activities and resources to facilitate efficiency and effectiveness of the delivery of public service goals. Numerous countries have begun to realize the 
importance of good financial management in public sector entities, especially after the emerging of international accounting standards, many countries and some intergovernmental organizations adopted IPSAS because it considers the best practices and alternative reforms for government entities in evaluating financial reports (Sarim, 2017).

The harmonization of public sector accounting generates outcomes similar to those of the business sector, although public sector accounting is considered less important than private sector accounting in the international market. Developed and developing countries should pay considerable attention to the global clamor for efficient public financial management that ensures accountability and transparency (Chan, 2003). World Bank (WB), International Monetary Fund (IMF), and Asian Developed Bank (ADB) are the main sponsors of financial reforms in less developed countries (LDCs).Since 1980, they have initiated programs for budgeting and accounting reforms in the public sector of LDCs, which are also the key features of New Public Management (NPM), proposed for LDCs to improve transparency and accountability in resource allocation and service delivery (Chan, 2003). Changes in global trend and the involvement of international institutions motivate the Government of Pakistan (GOP) to implement a paradigm shift in public sector financial management accordance with the best international practices. The GOP has modified its legislation to implement the reforms under Ordinance 2001 (javed \& wang, 2018).

\section{Literature Review}

Public Sector Accounting Reforms in Pakistan Since independence has been implementing the British accounting system, which is based on Accounting Code I-IV. This accounting system is dual in nature (Javed \& Wang, 2018). The British army, deployed in the subcontinent, maintains separate accounts and uses a different format for the civil sector, while public sector accounting follows the non-commercial system. Global harmonization in public sector accounting prompts the government to introduce reforms in the government accounting practice in Pakistan. The PIFRA reforms were begun in the 1990s. Currently, the NAM is implemented using the SAP/R3 application for government accounting. The current accounting reforms in the government sector of Pakistan were initiated in 1997 through PIFRA and financed by World Bank (WB) under the supervision of the AG of Pakistan. The major change in the accounting system involves separating the office of the AG from the Controller General of Accounts (CGA) through ordinance 2001(Javed \& Wang, 2018). The IMF conducted a survey for reforms through a diagnostic study sponsored by WB and project partner ADB. The accounting and auditing system of all government entities of Pakistan were obsolete and required harmonization.

Inadequate system for financial data, and lack of skilled staff resulted in unsatisfactory planning, budgeting and reporting, and ineffective internal controls. Cash, asset, and debt positions were unreliable (JARUGA, 26). Some commitments/obligations were unidentified. Pensions and depreciation records were not maintained. These contributing factors caused uneven resource allocation and led to weak governance and accountability (Chan, 2003). Project to Improve Financial Reporting and Auditing mainly aimed to guarantee transparency in government and donor development funds, enhance the accountability of government revenue and expenditure, reinforce the decision-making and budgeting processes, as well as offer realistic information to the public. IPSAS supports transparency and accountability in public sector organizations and improves the quality of financial information reporting. The main purpose of IPSAS is to improve the quality of the general-purpose financial reports (GPFRs) of public sector entities for decision-making and allocation of resources (Accrual Practices and Reform Experiences in OECD Countries, n.d).

Compliance with IPSAS standards ensure that the financial reporting of public entities reflects a true and fair view of the financial position and shows transparency and accountability in the management of public resources (Azmi, 2014). It brought excellence in financial management and thereby increasing the confidence of investors and gaining public trust. IPSAS enables the comparison of financial reports with those of other countries and motivate raising capital from international markets (Capechieno, 2000). Sovereign debt crisis, which has affected many countries, including the European Union and the United States, is caused by the lack of government transparency and accountability, poor financial management, poor public sector financial reporting, and the lack of institutions for fiscal management; these weaknesses constrain the government from managing financial resources to protect the interests of the public and other investors (Adhikari, 2011). The establishment of the World Trade Organization and the partnership agreement between countries force developing countries to implement reforms in their economic and development policies and move to NPM to integrate with the world economy (Ouda, 2004).

The healthier financial management ensured greater accountability and transparency, alleviated the apprehension of both developed and under developed countries, and reduced anxiety by using IPSAS in preparing the GPFRs 
designed and promoted by the International Federation of Accountants (Godfrey, 2001). The basic aim of IPSAS is to improve the quality of public sector GPFR, ensure government transparency and accountability, and promote the assessment of resource allocation decisions and conformity with global best practices and sustainability reporting. Financial stewardship is promoted and all stakeholders have great confidence in public sector organizations; effective financial management plays an important role in decision-making and resource allocation (Narayan, 2000).

The cash accounting approach, that has been the predominant accounting system in the public sector has failed to address meaningful shortcomings of the financial reporting inadequacies and information reporting by government entities (Rauf et al., 2012). Cash accounting system opponents argue that the system rarely provides more information into the financial well-being of an organization but rather focuses more on the cash inflows, outflows, and cash balances held by the organization after expenditure (IFAC, 2000). Moreover, the cash accounting system rarely provides information on the on going concern of a company and this tends to hinder the public from making an effective decision concerning a government entity as it lacks prompt data on the liabilities, and assets in the financial reports (PwC, 2013). Due to its limiting nature, the system fails to offer insights into the operational cost of an organization in its quest for service delivery to the public (Hoque \& Moll, 2001).On the contrary, proponents of accrual accounting argue that the system can offer accurate information on government's financial positions, the operational cost of the entity, assets and liabilities will be reported in the financial statement (Isa et al., 2014). These limitations prompted the need to shift from the cash accounting system to the accrual accounting system of financial reporting. The proponents of this new method argue that the system allows for the better information of public sector finances, effective decision-making opportunity, precise representation of the costs, assets and liabilities (Connolly \& Hyndman, 2006).

A study carried out in Greece regarding the implimentation of accrual accounting indicates that the adoption of accrual accounting in the public sector in Greece is quite low after six years of regulation (Shah, 2007). The study also suggests contingency factors that have proven positive effects and significance to the level of adoption of accrual accounting, which include factors such as staff education level, training, information technology quality and support consultant. There are also factors that proven to no significant influence on the matter at hand, such as experience, leadership, education and organizational size (Suparman et al., 2015).Investigated factors influencing the adoption of accrual accounting in Indonesia suggests that their significant barrier in the adoption of accrual-based accounting system as a willingness to change. The study revealed that strong political support and leadership is required to transit from cash to accrual accounting. (Upping and Oliver, 2012). In the Examination of the factors influencing implementation of an accrual-based accounting system in public institutions of higher learning in Thailand, a conclusion was made that institutional capacity about technological resources and knowledge of staff is the key aspects required to implement the accounting shift, successfully in the universities. Other affecting factors discovered by prior studies include support from senior leadership and management teams, the interest of international organizations and involvement of professional accounting bodies (Adhikari \& Mellemvik, 2011; Azmi \& Mohamed, 2014).

\section{Research Methodology}

This section of the study adopts principles of research methodology which elaborates the process adopted for obtaining data from a sample group in order to attain the objectives of the study and ensure useful information is provided from the respondents of the study (Helen, 1993). In a research study, the study population can be defined as the collection of participants, materials and measurement and analysis tools relevant to the study design . This study adopts the administrative staff as the study sample population. The research utilized simple random sampling technique to attain a reasonable population that would validate the purpose of the study (Bancrof, 1997). A random selection of accounting practitioners was carried out and a sample size of 360 respondents was obtained. The sample population came from four accounting divisions within the GOP finance sector, which included the Accounts Division, Revenue, Budgetary Unit and the Audit Unit (Becker, 2014). In an attempt to address the research questions which could contribute to the challenges encountered implementation of the accrual accounting in the public sector of Pakistan, the research examined one dependent variable against two independent variables. The dependent variable in particular was the implementation challenges while the two independent variables were the level of training and accounting education, and the different levels of cost. The research also adopted similar studies that elaborated the implementation of his financial approach on both developing and emerging nations, with conditions applicable to various areas with similar standards and orientation (Pollitt, 2011). These literatures were useful in determining a standard margin of the outcomes. 


\section{Results}

The table below performs a descriptive statistics evaluation of the accounting education and training.

Table 1. Descriptive statistics evaluation of the accounting education and training

\begin{tabular}{|c|c|c|c|c|c|}
\hline & $\mathbf{N}$ & Min & Max & Mean & $\begin{array}{l}\text { Std. } \\
\text { Dev }\end{array}$ \\
\hline There exists lack of proper professional accounting in the public sector & 360 & 1.00 & 5.00 & 4.2336 & .84731 \\
\hline There is lack of adequate structure to support the business process & 360 & 1.00 & 5.00 & 4.3911 & .79125 \\
\hline There is little public knowledge of A IPSAS & 360 & 1.00 & 5.00 & 4.4021 & .76889 \\
\hline Present accounting practitioners have little knowledge of AIPSAS implementation & 360 & 1.00 & 5.00 & 4.2101 & .85640 \\
\hline The educational curricular offered does not offer extensive knowledge on AIPSAS & 360 & 1.00 & 5.00 & 4.1209 & .94325 \\
\hline $\begin{array}{l}\text { The GOP public sector has offered limited access and exposure to training materials relating to } \\
\text { AIPSAS implementation }\end{array}$ & 360 & 1.00 & 5.00 & 4.1925 & .86287 \\
\hline There is insufficient monitoring by the internal audit due to inadequate capacity and skilled staff & 360 & 1.00 & 5.00 & 4.1712 & .88361 \\
\hline Insufficient training and experiences offered to decision makers & 360 & 1.00 & 5.00 & 4.1165 & .95123 \\
\hline
\end{tabular}

The Table 1 depicts the minimum value of the mean as 4.1165 with a standard deviation of 0.95123 and the maximum value of the same as 4.4021 with a standard deviation of 0.76889 . The highly obtained mean values mean that the most respondents from the study concurred that there existed challenges of AIPSAS on the financial management of the Pakistani Public sector. Similarly, from the mean and the standard deviation obtained from the eight-point Likert type scale, the level of education offered by the GOP is confirmed to be quite lacking especially on the studies and implementation of AIPSAS. The table 2 depicts the descriptive statistics of the different levels of cost.

Table 1. Descriptive statistics of the different levels of cost

\begin{tabular}{|c|c|c|c|c|c|}
\hline & $\mathbf{N}$ & Min & Max & Mean & $\begin{array}{l}\text { Std. } \\
\text { Dev }\end{array}$ \\
\hline Estimating the cost of AIPSAS implementation is difficult & 360 & 1.00 & 5.00 & 4.3326 & .94761 \\
\hline The cost of research on AIPSAS as a new financial management approach is high & 360 & 1.00 & 5.00 & 4.2311 & .84125 \\
\hline The cost of training personnel for adoption of AIPSAS is relatively high & 360 & 1.00 & 5.00 & 4.6551 & .81889 \\
\hline The cost of acquiring software and hardware required for AIPSAS implementation is high & 360 & 1.00 & 5.00 & 4.9161 & .89646 \\
\hline $\begin{array}{l}\text { The cost of acquiring new accounting packages needed for the implementation process is } \\
\text { relatively high }\end{array}$ & 360 & 1.00 & 5.00 & 4.3279 & .94325 \\
\hline $\begin{array}{l}\text { The cost of transitioning to the new financial system which include discarding existing previous } \\
\text { accounting packages not relevant with AIPSAS operations is high }\end{array}$ & 360 & 1.00 & 5.00 & 4.1925 & .85267 \\
\hline The cost of installing and maintaining the new accounting packages within AIPSAS is high & 360 & 1.00 & 5.00 & 4.2782 & .99361 \\
\hline Ideally, the cost incurred while organizing seminars and manuals on AIPSAS is also high & 360 & 1.00 & 5.00 & 4.1264 & .90123 \\
\hline
\end{tabular}

From the table, the minimum value observed from the mean values is 4.1264 with a standard deviation of 0.90123 while the maximum value of the mean is 4.9161 with a standard deviation value of 0.89646 . Similarly, the high positive value of the mean indicates that most respondents were in agreement that there existed implementation challenges of AIPSAS on the financial management of the Pakistani Public sector. The mean and standard deviation for the independent variable performed with eight items on a five-point Likert type scale additionally indicates that the financial management of the Pakistani Public sector faces cost challenges in the implementation of AIPSAS.

\subsection{Pearson Correlation Results Analysis}

This analytical method measures the correlation between two variables and is linear in nature. The measurement provides a value between +1 and -1 . It is widely adopted to provide measurements of strength of linear dependence between two variables. The P-value in this approach attempts to provide the measurement of the 
strength of results rather than adopting a hypothetical approach of concluding particular results are rejected or not rejected. For this study, it is important to note that the relationship (r) performs an important role in the determination of the level of relationship among the variables. A p-value $p<0.05$ is also used in relationship establishment. It implies there is only $5 \%$ chance that the relationship is non-existent. This alternatively implies there is $95 \%$ the variables are correlated. Below is a table illustrating the Pearson correlation analysis among the variables and consequently testing the hypotheses.

Table 3. Pearson correlation analysis

\begin{tabular}{llllll}
\hline & DP & Level of ACC & Level of Cost & Exist Law & CULPRA \\
\hline DP & 1.000 & & & & \\
Level of ACC & .778 & 1.000 & & & \\
Level of Cost & .869 & .813 & 1.000 & & \\
\hline
\end{tabular}

This table shows significant correlations between the two independent variables. From the results indicated, a conclusion can be drawn that there are positive relationships between the two independent variables and the implementation process of AIPSAS. Form the value of the correlation coefficient of accounting (0.778), a conclusion can be drawn that as the level of accounting training increases, challenges of IPSAS implementation also increase.

Multiple regression analysis can also be used to determine the factors that could affect the implementation of IPSAS by the financial sector of Pakistan. To utilize the regression analysis; the study adopted four independent variables tested against the dependent variable. These functional relationships include the implementation of IPSAS is a level of learning prerequisite, existing laws, varying levels of costs and cultural practices.

Table 2. Correlations

\begin{tabular}{lllll}
\hline Model & R & R Square & Adjusted R Square & Std. Error of the Estimate \\
\hline 1 & .878 & .784 & .783 & 1.87563 \\
\hline
\end{tabular}

From this table, both the $\mathrm{R}$ squared and the adjusted $\mathrm{R}$ squared measure the model fitness. The table provides a significance of $\mathrm{F}(4 \mathrm{479})=474.264 \mathrm{P}=000$. Considering the adjusted $\mathrm{R}$ squared is the modifier for the limitation of $\mathrm{R}$ squared, its value is therefore considered as the measure for fitness in this model. The value of adjusted $\mathrm{R}$ squared from the table is 0.783 , which indicates the independent variables are explaining $80.3 \%$ variation in the dependent variables. This insinuates that the model of study provides a reliable fit for the data and inherently explains that the independent variables are the main determinants of implementation challenges of AIPSAS. From the table, an observation that the independent variables have a great effect on the dependent variable where $\mathrm{F}$ value is 832.147 with a p-value of less than 0.05 which is an indication that the overall model used was appropriate in explaining the variation on the dependent variable. Ultimately, this study indicates a positive relationship between the levels of accounting education and the training and implementation process of AIPSAS. Notably, a regression coefficient of 0.301 and a p-value 0.000 is achieved revealing there is a positive relationship all the independent variables and the dependent variable.

\section{Discussion}

This section attempts to provide an explanation as to why the implementation of AIPSAS is a challenge in the public sector of Pakistan. From the statistical analysis performed using regression and correlation methods, conclusions can be made to reject or fail to reject the stated hypotheses. The results from the above section show that there is significant relationship between the variables being tested. The level of accounting education for instance and training, and the cost factor and finally the tested dependent variable have a significant relationship. As a result, the independent variable is test results are compared to the existing related studies, the formulated hypotheses and theoretical predictions of the study. Concerning the level of public awareness of AIPSAS, a conclusion can be made that there is little effort by the Pakistan government applies little effort towards campaigning for a compulsory implementation of the AIPSAS. This is evident from the fact that the majority of respondents were in agreement that there is little knowledge of AIPSAS. To determine whether accounting practitioners have the required knowledge of IPSAS, the research was in agreement with the survey conducted by the United Nations Conference on Trade and Development, which explained that the lack of proper personnel 
with international financial standards becomes a challenge in the implementation process. The study also records the respondents concurring with the lack of excellent knowledge and skills. 1in response to whether academic curricular pays attention to IPSAS, a negative response was obtained from the respondents which affirms the ascertain by the World Bank which concluded academic does not focus on the studies for financial international standards. To respond on the question investigating sufficiency of training and education for accounting practitioners in the implementation of AIPSAS, the outcome which is supported by the studies of UNCTDA that there is insufficient training and education for accounting practitioners. The problems stated within the five-point Likert scale between the two independent variables attained consistent results to the theoretical estimation and were proved by empirical studies conducted by the UNCTDA. Both the correlation and regression results indicate relationships between all independent and dependent variables. The results of the research ultimately do not reject the null hypotheses of the study.

\section{Conclusion}

From the analysis and discussion sections of this study, there is a clear indication that the financial management of the Pakistani Public sector experience challenges from AIPSAS implementation. From the study, a conclusion can be draw that the GOP does not take keenly the inclusion of the international standards of financial management including IPSAS into their academic curricular. This implies that there is lack of proper synchronization of developments between traditional professional training and the university training. Consequently, lack of adequate investment into this financial management venture at the training and educational level by the GOP, insufficient training and education in the discussed area becomes an inhibiting factor. Generally, the cost analysis experiential process determined that both the implementation cost and maintenance costs for IPSAS were high. This implies that professional bodies should be responsible to properly perform the administrative and management roles and that the management of the financial system of the Pakistan Public sector should select and recruit qualified personnel to avoid the costs that would otherwise be allocated for training purposes.

The study therefore recommends the inclusion of IPSAS in the academic curricular of -higher learning institutions for instance, universities, colleges and profession bodies such as ICMAP, ICAP and PIPFA in Pakistan to help minimize the challenges experienced during adoption and implementation process. Additionally, the study discovered high cost of implanting new financial and accounting standards in the financial management system of the Pakistan Public sector and recommends the GOP to allocate additional funds to the financial sector to cater for additional costs whenever such new changes are to be implemented.

\section{References}

Accrual Practices and Reform Experiences in OECD Countries. (n.d.). Organisation for Economic Co-operation and Development.

Adhikari, P., \& Mellemvik, F. (2011). The rise and fall of accruals: A case of Nepalese central government. Journal of Accounting in Emerging Economies, 1(2), 123-143. https://doi.org/10.1108/20421161111138495

Azmi, A. H., \& Mohamed, N. (2014). Readiness of Malaysian public sector employees in moving towards accrual accounting for improve accountability: The case of ministry of education (MOE). Procedia-Social and Behavioral Sciences, 164, 106-111. https://doi.org/10.1016/j.sbspro.2014.11.057

Bancroft, N. H., Henning, S., \& Sprengel, A. (1997). Implementing SAP R/3: How to introduce a large system into a large organization. Greenwich, CT: Manning Publications Co.

Barton, A. (2005). Professional Accounting Standards and the Public Sector - A Mismatch. ABACUS, 41(2), 138-158. https://doi.org/10.1111/j.1467-6281.2005.00173.x

Becker, D., Sebastian, T. J., \& Peter, S. (2014). The Translation of Accrual Accounting and Budgeting and the Reconfiguration of Public Sector Accountants' Identities. Critical Perspectives on Accounting, 25(4-5), 324-338. https://doi.org/10.1016/j.cpa.2013.05.004

Caperchione, E., \& Mussari, R. (2000). Comparative issues in local government accounting. Boston: Kluwer Academic. https://doi.org/10.1007/978-1-4615-4581-1

Chan, J. L. (2003). Government Accounting: An Assessment of Theory, Purposes and Standards. Public Money \& Management, 23(1), 13-20. https://doi.org/10.1111/1467-9302.00336

Christensen, M. (2002). Accrual accounting in the public sector: the case of the New South Wales government. Accounting History, 7(2), 93-124. https://doi.org/10.1177/103237320200700205

Connolly, C., \& Hyndman, N. (2006). The Actual Implementation of Accruals Accounting: Caveats from a Case 
within the UK Public Sector. Accounting, Auditing \& Accountability Journal, 19(2), 272-290. https://doi.org/10.1108/09513570610656123

Deaconu, A., Nistor, C. S., \& Filip, C. I. (2009). The effect of transiting from cash accounting to accrual accounting on performance in the public sector. Studia Universitatis Babes_BolyaiOeconomica, 54, $115-129$

Department of Technical Co-operation for Development. (1984). Accrual accounting in developing countries. New York: United Nations.

Egol, M. (1987). Can accrual accounting work in Governmentll, Can Accrual Accounting work in Government (pp. 1-7). Federation of Accountants Financial statements, the Federal Government of Pakistan Financial Year 2015-2016.

Godfrey, A., Devlin, P., \& Merrouche, C. (2001). A Diffusion-Contingency Model for Government Accounting Innovations. In Acd Bac (Ed.), International Comparative Issues in Government Accounting: The Similarities and Differences between Central Government Accounting and Local Government Accounting within or between Countries (Chapter 17, pp. 279-296). https://doi.org/10.1007/978-1-4757-5563-3_17

Guthrie, J. (1998). Application of Accrual Accounting in the Australian Public Sector - Rhetoric or Reality? Financial Accountability and Management, 14(1), 1-18. https://doi.org/10.1111/1468-0408.00047

Helen, L., \& Dulock, R. (1993). Research designed: Descriptive research. Journal of Pediatric Oncology Nursing, 10(4), 154-157. https://doi.org/10.1177/104345429301000406

Hepworth, N. (2003). Preconditions for Successful Implementation of Accrual Accounting in Central Government. Public Money and Management, 23(1), 37-44. https://doi.org/10.1111/1467-9302.00339

Hodges, R., \& Mellett, H. (2003). Reporting Public Sector Financial Results. Public Management Review, 5(1), 99-113. https://doi.org/10.1080/1461667022000028870

Hoque, Z., \& Moll, J. (2001). Public Sector Reform: Implications for Accounting, Accountability and Performance of State-Owned Entities- An Australian Perspective. International Journal of Public Sector Management, 14(4), 304-326. https://doi.org/10.1108/09513550110395256

Hyndman, N., \& Connolly, C. (2011). Accruals accounting in the public sector: A road not always taken. Management Accounting Research, 22(1), 36-45. https://doi.org/10.1016/j.mar.2010.10.008

IFAC. (2000). Government Financial Reporting: Accounting Issues and Practices. New York: International Federation of Accountants.

International Public Sector Committee. (2002). Transition to the accrual basis of accounting: Guidance for governments and government entities. New York: International Federation of Accountants.

Isa, C. R., Saleh, Z., \& Hasan, H. A. (2014). Transition towards Accrual Accounting: Commitment to Change in the Malaysian Public Sector Articles of Merit Award on PAIB 2013 (pp. 37-48). Kuala Lumpur: Malaysian Institute of Accountants.

Ismaila, B. et al. (2004). Public financial accountability in Pakistan the Impact of PIFRA on capacity. Capital enhancement brief, World Bank Institute.

Jaruga, A., \& Nowak, W. A. (1996). Toward a General Model of Public Sector Accounting Innovations. Research in Governmental and Nonprofit Accounting, 9, 21-31.

Javed, M., \& Zhuquan, W. (2018). Analysis of Accounting Reforms in the Public Sector of Pakistan and Adoption of Cash Basis IPSAS. Universal Journal of Accounting and Finance, 6(2), 47-53. https://doi.org/10.13189/ujaf.2018.060203

Lüder, G. K. (1992). A Contingency Model of Government Accounting Innovation in the Political Administrative Environment. Research in Governmental and Nonprofit Accounting, 7, 99-127.

Meiliana, S., Siti-Nabiha, A. K., \& Lian, K. P. (2015). Public sector accounting reforms: assessing Indonesia's readiness towards implementing accrual accounting. Problems and Perspectives in Management, 13(2-si).

Monteiro, B. R. P., \& Gomes, R. C. (2013). International experiences with accrual budgeting in the public sector. Revista Contabilidade\&Finanças, 24(62), 103-112. https://doi.org/10.1590/S1519-70772013000200002

Narayan, F. B., \& Godden, T. (2000). Financial management and governance issues in Pakistan. Manila: Asian Development Bank. 
OECD. (1995). Governance in transition: public management reforms in OECD countries. Paris: OECD.

Ouda, H. G. (2004). Basic Requirements Model for Successful Application of Accrual Accounting in the Public Sector. Public Fund Digest, 4(1), 78-99.

Ouda. H. G. (2001). Basic Requirements Model for Successful Application of Accrual Accounting in the Public Sector. 8th Biennial CIGAR Conference: Innovations in Governmental Accounting. Comparative International Government Accounting Research (CIGAR) and University of Valencia. Valencia.

Pakistan annual Law Digest. (1967). Lahore: Pakistan Annual Law Digest Office.

Pakistan. (1974). Foreign affairs Pakistan. Islamabad: Pakistan, Ministry of Foreign Affairs.

Pollitt, C. (2003), Public management reform: reliable knowledge and international experience. OECD Journal on Budgeting, 3(3), 121-36. https://doi.org/10.1787/budget-v3-art19-en

Pollitt, C., \& Bouckaert, G. (2011). Public management reform a comparative analysis: New public management, governance, and the neo-Weberian state (3rd ed.). New York, NY: Oxford University Press.

Public Sector Committee. (1996). Perspectives on accrual accounting, Occasional paper 3.

PwC. (2013). PwC Global survey on accounting and financial reporting by central governments: Towards a new era in government accounting and reporting, PwC.

Rauf et al. (2012). Public Sector Accounting-Malaysian Context (3rd ed.). Pearson Malaysia Sdn Bhd.

Regan, E. (1987). Accrual accounting in government, Can Accrual Accounting Work in Government.

Sariman et al. (2017). Issues and Strategies of Accrual Accounting Implementation in Malaysia: A Comparative Study between Federal Government and State Governments. International Journal of Business Management, 2(2).

Shah, A. (2007). Budgeting and budgetary institutions. Washington, D.C: World Bank. https://doi.org/10.1596/978-0-8213-6939-5

Stamatiadis, F., Eriotis, N., \& Vasiliou, D. (2009). Assessing Accrual Accounting Reform in Greek Public Hospitals: An Empirical Investigation. International Journal of Economics Science and Applied Research, $4(1), 153-184$.

United Nations \& United Nations Expert Group Meeting on Public Accounting and Auditing. (1984). Accrual accounting in developing countries. New York: United Nations

Upping, P., \& Oliver, J. (2012). Thai public universities: modernisation of accounting practices. Journal of Accounting \& Organizational Change, 8(3), 403-430. https://doi.org/10.1108/18325911211258362

\section{Copyrights}

Copyright for this article is retained by the author(s), with first publication rights granted to the journal.

This is an open-access article distributed under the terms and conditions of the Creative Commons Attribution license (http://creativecommons.org/licenses/by/4.0/). 